\title{
Seed Size Studies in Relation to Quality Attributing Parameters in Chickpea Variety GBM-2
}

\author{
B. S. Ganiger*, Basave Gowda, Umesh Hiremath, G. Y. Lokesh and L. Rekha \\ National Seed Project (Crops), Seed Unit, University of Agriculture Sciences, \\ Raichur, Karnataka, India \\ *Corresponding author
}

\section{Keywords \\ Chickpea, GBM-2, IMSCS, Pure Live Seed (PLS), Sieve size, Slotted shape \\ Article Info \\ Accepted: \\ 14 June 2020 \\ Available Online: \\ 10 July 2020}

\begin{abstract}
A B S T R A C T
Seed processing is the most important component of quality seed production in achieving the prescribed physical seed standards wherein seed grading is the vital practice for better crop establishment and also useful in separation of quality seed in a seed lot. In this context, the present study on tracing optimum sieve size for size grading, maximum recovery of seeds and seed quality parameters in chickpea variety GBM-2 was conducted using oblong/slotted shape sieve of size $5.0 \mathrm{~mm}, 5.5 \mathrm{~mm}, 6.0$ $\mathrm{mm}, 6.5 \mathrm{~mm}$ and $6.75 \mathrm{~mm}$. On the basis of two years data, the results revealed that $5.0 \mathrm{~mm}$ sieve recorded higher seed recovery $(98.66 \%)$ than other sieves with better seed quality parameters viz. germination percentage (87.00\%), 100 seed weight (18.34 grams), pure live seed $(85.69 \%)$ and physical purity $(98.07 \%)$. The recovery of good seed is found to increase to the extent of 3.0 to 4.0 per cent. Hence, seeds of chickpea variety GBM2 could be size graded with $5.0 \mathrm{~mm}(\mathrm{~S})$ sieves for more seed recovery with Indian Minimum Seed Certification Standards (IMSCS) for seed grading.
\end{abstract}

\section{Introduction}

There are about 60 domesticated grain legume species in the world (Hedley, 2001). Chickpea (Cicer arietinum L.) is one of the most important grain legumes as it ranks third in the world after dry bean (Phaseolus vulgaris L.) and field pea (Pisum sativum L.) [FAO (2004)]. It is an important source of protein, carbohydrate, B-group vitamins, and certain minerals (Williams and Singh, 1988), particularly to the populations of developing nations (Chavan et al., 1987). It is an important source of cheap protein with high energy and nutritive value (Hulse, 1991; ElKaramany and Bahr, 1999).

The seed represents the most critical and valuable inputs in agriculture and quality seed are the foundation for successful agriculture. 
In view of the shrinking natural resources in terms of the land, water, nutrients and changing global climate, quality seeds of improved varieties assume paramount importance. Quality seed is not only the carrier of genetic potential but it also ensures greater planting value having better germination, seed vigour, being free from seed borne pathogens and having been fortified by nutrients, pesticides and growth promoting substances. Healthy and vigourous planting material is one of the major requirements to obtain high yield and more returns for efforts put into land cultivation. Further, population at global, in particular India, is increasing at an alarming level demanding substantial increase in food production to feed this ever increasing population. Accordingly, with the view to increase the food production government in most of the countries have now recognized the need to produce quality seeds and have prescribed seed standards for marketing purposes.

Seed processing is the most important component of quality seed production in achieving the prescribed physical seed standards and is therefore recognized as an important and integral part of the seed production system. Production of seed in field can seldom be planted in the condition in which it comes from the growers. In fact seed received from the field are having a high moisture content and comprise trash and other inert material, weed seeds, deteriorated and damaged seeds, off-sized seeds etc. Seed processing is necessary in order to dry the seeds to safe moisture level, remove or reduce to the extent possible the various undesirable material, weed seeds, other crop seeds, deteriorated or damaged seeds, uniform size grading for better planting and to apply chemical protectants before packaging and storage to upgrade the overall seed quality.
Seed size is one of the important yield components which have an effective role on cultivar adaptation to different condition with affecting the seed vigour (Morrison and Xue, 2007). Between the genetically factors, seed size has a special role in crop production. Studies of Roozrokh et al., (2005) on chickpea showed that large seeds of chickpea had high germination percentage, more seedling dry weight and better electrical conductivity in compare with small seeds. The effect of seed size continues to predominate in determining field stand and uniform crop growth (Dubey et al., 1989). Seed size affected the germination and emergence potential (Dharmalingam and Ramakrishnan, 1978). Seed size also influences the yield (Bhingarda and Dumbre, 1993).

Size is a widely accepted measure of seed quality and large seeds have high seedling survival growth and establishment (Jerlin and Vadivelu, 2004). University of Agricultural Sciences, Raichur, Karnataka, India has developed new chickpea variety GBM-2 in 2016 suitable for mechanical harvesting to avoid the problem of labour unavailability at the harvesting time. This variety bears pods only on top portion and plants will grow tall with a height of 60-70 centi meters. The duration of variety is 100-110 days with potential yield of 15-18 quintals per hectare.

At present the sieve size of $6.0 \mathrm{~mm}$ has been suggested by Seed Certification Agency to process the chickpea seeds. It is often observed that the seed growers are losing considerable quantity of good seed which is treated as a rejection and considering the huge demand from farmers for certified seed production. Therefore, there is an urgent need to standardize the sieve size for grading chickpea variety GBM-2 seeds. Hence, the present investigation on optimum sieve size and type of screen for grading chickpea 
variety GBM-2 seeds was planned and undertaken on the basis of large scale seed processing.

\section{Materials and Methods}

The experiment was conducted at Seed Unit, University of Agricultural Sciences, Raichur, during the year 2014 and 2015. The bulk seeds of chickpea variety GBM-2 harvested from the crop raised at seed unit, UAS, Raichur constituted the materials for the study. The collected seeds were tested for seed recovery percentage, germination percentage, physical purity percentage, 100 seed weight (gram), seedling vigour index-I and pure live seed. The pre-cleaned seeds of chickpea variety GBM-2 were graded with slotted shape sieve of $5.0 \mathrm{~mm}, 5.50 \mathrm{~mm}, 6.0$ $\mathrm{mm}, 6.50 \mathrm{~mm}$ and $6.75 \mathrm{~mm}$ size. For grading the seeds "Cleaner cum grader" having two screens and one fan were used. The Seeds retained over each sieve size were collected separately and tested for quality parameters i.e. recovery percentage and physical purity percentage (ISTA, 1993), 100 seed weight (ISTA, 1999) was expressed in gram. For germination testing, 100 seeds were germinated at the temperature of $25 \pm 2{ }^{\circ} \mathrm{C}$ and $90 \pm 2 \%$ of relative humidity in four replications. After 8 days the seedlings were evaluated and normal seedlings were counted and expressed in per cent as per ISTA (1999). The Pure live seed was calculated using following formula:

Pure Live Seed $($ PLS $)=$

Physical purity (\%) X Germination (\%) 100

Seed recovery percentage $=$

Weight of seeds retained in each sieve

Total weight of seeds x 100
The seedling vigour index-1 was calculated by adopting the method suggested by Abdul Baki and Anderson (1973) and expressed in number by using the following formulae. Seedling Vigour index $-\mathrm{I}=$ Germination percentage $\times$ Seedling length in centimetre

The experiment was laid out in a completely randomized design with four replications. The results were subjected to analysis of variance and expressed at $1 \%$ level of probability. An Arcsine transformation was used for percentage data.

\section{Results and Discussion}

Seed as it comes from a field is often mixed with impurities like seeds of weeds and other plants, plant debris, soil and stones, which must be separated to obtain pure live crop seeds for sowing. During seed processing, seeds first go through a pre-cleaning operation, then the seed is processed on an air-screen cleaner in which bulk of the foreign material is removed by screens and air. The final separation is achieved on one or more finishing machines, which normally separate only one type of contaminating seed from the desired seed. The purpose of grading is to improve the homogeneity of the seed lot by removing seeds of the same species with low quality during size grading. The small seeds are discarded which are believed to include empty, underdeveloped and low vigorous seeds. Importance of seed size was reported by Ramesh (1996), Menaka and Balamurugan (2008). Seed size is an important physical indicator of seed quality that affects vegetative growth and is frequently related to yield, market grade factors and harvest efficiency.

Seed separation is accomplished by the use of special equipment that utilizes differences in physical characteristics of various components in the mixtures. The chief 
characteristics by which separations are made are size, shape, density, surface texture, color, and electrical properties. In the present study, the seeds retained by $5.0 \mathrm{~mm}$ sieve recorded more recovery percentage followed by 5.5 $\mathrm{mm}$ than the other sieve, but germination percentage was maximum in $5.5 \mathrm{~mm}$ compared to $5 \mathrm{~mm}$ sieve. Similar observations of improved seed recovery and quality have been reported by many workers (Hanumantharaya, 1991 and Ramaiah, 1994).

Seed from each crop is basically different in physical make-up from others and can be identified easily. The physical differences in size, shape, weight, surface area, specific gravity, colour, texture, stickiness, pubescence and electrical properties can be measured or sensed by mechanical devises called separators, which cull unwanted impurities from the seeds on the basis of one or more of these physical differences. Cleaning thus reduces the bulk to be handled and stored and removes moist and green plant material that may cause heating in storage. Scientific seed production recognizes the importance of seed processing to maintain the physical purity of seeds besides recovery of optimum sized seeds for uniform crop establishment and growth. In the present investigation, physical purity was highest in $6.75 \mathrm{~mm}(98.84 \%)$ sieve \& lowest in $5.0 \mathrm{~mm}$ $(98.07 \%)$. Whereas, $5.5 \mathrm{~mm}$ sieve size seeds recorded $98.31 \%$ physical purity and difference is very negligible in other sieves. Pure live seed was highest in $6.5 \mathrm{~mm}$ sieve size seeds followed by $5.5 \mathrm{~mm}$ sieve size seeds.

Germination percentage was more than $87 \%$ in all sieve size seeds (range 87-92\%), and there was no significant difference between germination percentage among all sieves. Increase in germination percentage was observed with increase in seed size. Highest germination percentage was observed in 6.0 $\mathrm{mm}$ and $6.5 \mathrm{~mm}$ (92\%) (Table 1). Farhoudi (2010) reported no significant difference between seed size on germination and for both seed sizes and all salinity treatments were greater than $90 \%$ (range 90-97\%) in safflower. Rukavina (2002) in barley reported the same results. These results are in agreement with our findings. For instance, Gunaga et al., (2007) have recorded higher seed germination and seedling vigour by using bigger sized seeds in Pongamia pinnata and Vateria indica. $5.0 \mathrm{~mm}$ sieve size recorded highest recovery percentage followed by $5.5 \mathrm{~mm}$, even though and $5.0 \mathrm{~mm}$ recorded lowest germination percentage, it meets the minimum seed certification standards, germination percentage, and hence $5.0 \mathrm{~mm}$ sieve size is good for processing. Vishwanath and Ravi Hunje (2018) studied the influence of seed size grading on seed quality parameters soybean variety DSb 21 seeds using 3.75, 4.00 and $4.80 \mathrm{~mm}$ of round perforated metal sieves and found that 3.75 $\mathrm{mm}$ recorded highest recovery, seed germination, seedling vigour index-I, seedling vigour index -II, test weight, reduced electrical conductivity of seed leachates and higher field emergence. They concluded that grading soybean variety DSb 21 with 3.75 $\mathrm{mm}$ sieve size is more effective for obtaining seeds meeting seed certification seeds.

To obtain high-quality seed that will increase farm production and provide uniform raw material for industry, efficient seed-cleaning practices are necessary. Even though many types of machines are used for special seed separations, it is estimated that at least 50 percent of good seed is lost in cleaning and handling because it is damaged, or not sufficiently cleaned to meet quality standards set by seed laws, or certification requirements (Jesse et al., 1961). To assist in reducing these gigantic losses, research on seed processing is very much essential. 
Table.1 Effect of sieve size on seed quality of Chickpea variety GBM-2

\begin{tabular}{|c|c|c|c|c|c|c|c|c|c|c|c|c|c|c|c|c|c|c|}
\hline \multicolumn{7}{|c|}{2014} & \multicolumn{6}{|c|}{2015} & \multicolumn{6}{|c|}{ Pooled data } \\
\hline Treatments & $\begin{array}{c}\text { Recovery } \\
(\%)^{*}\end{array}$ & $\begin{array}{c}\text { Physical } \\
\text { purity } \\
(\%)^{*}\end{array}$ & $\begin{array}{c}\text { Germination } \\
(\%)^{*}\end{array}$ & $\begin{array}{c}100 \\
\text { seed } \\
\text { weight } \\
(\mathrm{g})\end{array}$ & $\begin{array}{l}\text { Seedling } \\
\text { vigour } \\
\text { index-I }\end{array}$ & $\begin{array}{l}\text { Pure } \\
\text { Live } \\
\text { Seed }\end{array}$ & $\begin{array}{c}\text { Recovery } \\
(\%)^{*}\end{array}$ & $\begin{array}{c}\text { Physical } \\
\text { purity } \\
(\%)^{*}\end{array}$ & $\begin{array}{c}\text { Germination } \\
(\%)^{*}\end{array}$ & $\begin{array}{c}100 \\
\text { seed } \\
\text { weight } \\
(\mathrm{g})\end{array}$ & $\begin{array}{l}\text { Seedling } \\
\text { vigour } \\
\text { index-I }\end{array}$ & $\begin{array}{l}\text { Pure } \\
\text { Live } \\
\text { Seed }\end{array}$ & $\begin{array}{c}\text { Recovery } \\
(\%)^{*}\end{array}$ & $\begin{array}{c}\text { Physical } \\
\text { purity } \\
(\%)^{*}\end{array}$ & $\begin{array}{c}\text { Germination } \\
(\%)^{*}\end{array}$ & $\begin{array}{c}100 \\
\text { seed } \\
\text { weight } \\
(\mathrm{g})\end{array}$ & $\begin{array}{l}\text { Seedling } \\
\text { vigour } \\
\text { index-I }\end{array}$ & $\begin{array}{l}\text { Pure } \\
\text { Live } \\
\text { Seed }\end{array}$ \\
\hline $5.0 \mathrm{~mm}\left(\mathrm{~S}_{1}\right)$ & $\begin{array}{c}98.48 \\
(83.11)\end{array}$ & $\begin{array}{c}98.11 \\
(82.11)\end{array}$ & $\begin{array}{c}87.50 \\
(69.34)\end{array}$ & 13.22 & 1684 & $\begin{array}{c}85.95 \\
(67.94)\end{array}$ & $\begin{array}{c}98.84 \\
(83.82)\end{array}$ & $\begin{array}{c}98.03 \\
(81.98)\end{array}$ & $\begin{array}{c}87.00 \\
(69.09)\end{array}$ & 23.45 & 2956 & $\begin{array}{c}85.52 \\
(67.64)\end{array}$ & $\begin{array}{c}98.66 \\
(83.39)\end{array}$ & $\begin{array}{c}98.07 \\
(52.04)\end{array}$ & $\begin{array}{c}87 \\
(69.20)\end{array}$ & 18.34 & 2320 & $\begin{array}{c}85.69 \\
(67.78)\end{array}$ \\
\hline $5.5 \mathrm{~mm}\left(\mathrm{~S}_{2}\right)$ & $\begin{array}{l}97.15 \\
(80.68)\end{array}$ & $\begin{array}{c}98.33 \\
(82.56)\end{array}$ & $\begin{array}{c}91.50 \\
(73.33)\end{array}$ & 13.63 & 1838 & $\begin{array}{c}89.97 \\
(71.73)\end{array}$ & $\begin{array}{l}97.35 \\
(80.66)\end{array}$ & $\begin{array}{c}98.29 \\
(82.49)\end{array}$ & $\begin{array}{c}93.00 \\
(75.48)\end{array}$ & 23.62 & 2903 & $\begin{array}{c}91.41 \\
(73.51)\end{array}$ & $\begin{array}{c}97.25 \\
(80.60)\end{array}$ & $\begin{array}{c}98.31 \\
(82.52)\end{array}$ & $\begin{array}{c}92 \\
(74.31)\end{array}$ & 18.63 & 3135 & $\begin{array}{c}90.69 \\
(72.56)\end{array}$ \\
\hline $6.0 \mathrm{~mm}\left(\mathrm{~S}_{3}\right)$ & $\begin{array}{c}94.73 \\
(76.73)\end{array}$ & $\begin{array}{c}98.61 \\
(83.25)\end{array}$ & $\begin{array}{c}92.00 \\
(73.79)\end{array}$ & 13.94 & 2048 & $\begin{array}{c}90.73 \\
(72.46)\end{array}$ & $\begin{array}{c}92.47 \\
(74.08)\end{array}$ & $\begin{array}{c}98.73 \\
(83.53)\end{array}$ & $\begin{array}{c}91.00 \\
(75.32)\end{array}$ & 23.85 & 3116 & $\begin{array}{c}89.59 \\
(71.20)\end{array}$ & $\begin{array}{c}93.60 \\
(75.35)\end{array}$ & $\begin{array}{c}98.67 \\
(83.39)\end{array}$ & $\begin{array}{c}91 \\
(72.99)\end{array}$ & 18.89 & 3396 & $\begin{array}{c}90.16 \\
(71.78)\end{array}$ \\
\hline $6.5 \mathrm{~mm}\left(\mathrm{~S}_{4}\right)$ & $\begin{array}{c}90.11 \\
(71.73)\end{array}$ & $\begin{array}{c}98.60 \\
(83.21)\end{array}$ & $\begin{array}{c}92.00 \\
(73.79)\end{array}$ & 14.08 & 2111 & $\begin{array}{c}90.71 \\
(72.41)\end{array}$ & $\begin{array}{c}89.89 \\
(71.46)\end{array}$ & $\begin{array}{c}98.88 \\
(83.92)\end{array}$ & $\begin{array}{c}92.00 \\
(73.34)\end{array}$ & 24.00 & 2877 & $\begin{array}{c}90.72 \\
(72.29)\end{array}$ & $\begin{array}{c}90.00 \\
(71.57)\end{array}$ & $\begin{array}{c}98.74 \\
(83.55)\end{array}$ & $\begin{array}{c}92 \\
(73.51)\end{array}$ & 19.04 & 3487 & $\begin{array}{c}90.71 \\
(72.31)\end{array}$ \\
\hline $6.75 \mathrm{~mm}\left(\mathrm{~S}_{5}\right)$ & $\begin{array}{c}88.95 \\
(70.59)\end{array}$ & $\begin{array}{c}98.66 \\
(83.36)\end{array}$ & $\begin{array}{c}89.7 \\
(71.50)\end{array}$ & 14.21 & 2174 & $\begin{array}{c}88.45 \\
(70.35)\end{array}$ & $\begin{array}{c}74.03 \\
(59.36)\end{array}$ & $\begin{array}{c}99.01 \\
(84.32)\end{array}$ & $\begin{array}{c}93.00 \\
(74.40)\end{array}$ & 25.78 & 3385 & $\begin{array}{c}92.08 \\
(73.69)\end{array}$ & $\begin{array}{c}81.49 \\
(64.52)\end{array}$ & $\begin{array}{c}98.84 \\
(83.82)\end{array}$ & $\begin{array}{c}91 \\
(72.95)\end{array}$ & 20.00 & 3803 & $\begin{array}{c}90.32 \\
(71.89)\end{array}$ \\
\hline F test & $\mathrm{S}$ & NS & NS & S & S & NS & $\mathrm{S}$ & S & NS & S & NS & NS & S & S & NS & $\mathrm{S}$ & $\mathrm{S}$ & NS \\
\hline Sem \pm & 0.95 & 0.17 & 1.55 & 0.09 & 58.81 & 1.41 & 0.27 & 0.32 & 1.45 & 0.25 & 186.28 & 1.28 & 0.52 & 0.22 & 1.26 & 0.10 & 100.08 & 1.13 \\
\hline CD@1\% & 3.94 & - & - & 0.38 & 245.10 & - & 1.12 & 1.4 & - & 0.96 & - & - & 2.15 & 0.92 & - & 0.43 & 417.06 & - \\
\hline
\end{tabular}

* values in parenthesis are arc sine transferred values 
Fig.1 Seed quality as influenced by sieve size in chickpea variety GBM-2




In the present experiment on standardization of sieve size for chickpea, seedling vigour index-I and 100 seed weight was increased with increase in sieve size. Highest seedling vigour index was observed in sieve size of $6.75 \mathrm{~mm}$ (3803) and lowest in 5.0mm (2320). 100 seed weight was significantly higher in $6.75 \mathrm{~mm}(20.09 \mathrm{gm})$ and lower in $5.0 \mathrm{~mm}$ (18.34 gm) (Table 1). Seed weight and seedling vigour index were related to the size of seed and food storage, as the sieve size increases, seed size also increases. Larger seeds containing more food in seeds compare to small size seeds, meanwhile 100 seed weight and seedling dry weight was maximum in large size seeds compared to small size seeds. These results are in confirmative with Wilenborg et al., (2005) and Mathur (1982) in oat, Farhoudi (2010) in safflower, Ghorbani (2008) in wheat. The positive association between size and weight of seeds was reported by Debchoudhury et al., (1995) in rapeseed, Kumar et al., (2005) in Indian mustard and Suma et al., (2014) in sesame. Attempts are being made to reduce seed losses by developing methods and equipment to improve efficiency in handling, treating, and separating crop seeds from weeds and inert matter. Ganiger et al., (2019) standardized the sieve size for seed grading in soybean $c v$. JS-335 seeds using $3.75 \mathrm{~mm}$, $4.00 \mathrm{~mm}, 4.25 \mathrm{~mm}, 4.5 \mathrm{~mm}$ and $4.75 \mathrm{~mm}$ of slotted perforated metal sieves and opined that larger sized seeds are obtained from $4.5 \mathrm{~mm}$ and $4.75 \mathrm{~mm}$ sieves with maximum germination and seedling vigour. Seed recovery percentage in $3.75 \mathrm{~mm}$ sieve was higher than other sieves and also quality of seeds obtained in $3.75 \mathrm{~mm}$ sieves was higher than the Indian Minimum Seed Certification Standards. The graded seeds obtained from the sieve $3.75 \mathrm{~mm}$ recorded the highest recovery (83.90\%), physical purity $(98.49 \%)$, germination $(75.00 \%)$, pure live seed $(74.11 \%)$ and other seed quality parameters and recommended the grading of soybean $\mathrm{cv}$.
JS-335 with $3.75 \mathrm{~mm}$ sieve which is more effective and economical.

Thus, the study indicated that, a sieve size of $5.0 \mathrm{~mm}$ can be considered as optimum for processing of chickpea variety GBM-2 with more recovery percentage (98.66 \%), with seed quality parameters in acceptable limits of seed standards and with an additional seed recovery $(\%)$ over the presently recommended sieve size.

\section{References}

Abdul Baki, A A and Anderson, J D., 1973. Vigour determination in soybean seed by multiple criteria. Crop Sci., 13: 630-633

Bhingarde, M T and A D Dumbre., 1993. Effect of seed size on growth and yield components in green gram (Vigna radiata L. Wilczek) under summer conditions. Seed Res., 21(2): 104-106.

Chavan, J K., Kadam, S S., Salunkhe, D K and Beuchat, L R., 1987. Biochemistry and technology of chickpea (Cicer arietinum L.) seeds. Crit. Rev. Food. Sci. Nutr., 25(2): 107-158.

Debchoudhury, A., Barua, P K. and P K Duara., 1995. Influence of seed size on crop performance in Indian rape seed. Seed Res., 23(2): 84-87.

Dharmalingam, C and V Ramakrishnan., 1978. Seed quality in relation to seed size and seed coat colour variation in Black Gram (Vigna mungo L. Hepper). Seed Res., 6: 101-109.

Dubey, A K., Singh, P., Goyal. R D and Katiar R P., 1989. A comparison of vigour between large and small seeds in Mustard. Seed Res., 17(2): 204-207.

El-Karamany, M F and Bahr, A A., 1999. Effect of mineral fertilization, organic manuring and biofertilization on yield and yield components of chickpea (Cicer arietinum L.) cultivars in sandy soil. Egypt J. Appl. Sci., 14(11): 68-76.

FAO., 2004. Production Yearbook 2003. Food and Agricultural Organization of the United Nations, Rome, Vol. 58. 
Farhoudi, R and M Motamedi., 2010. Effect of salt stress and seed size on germination and early seedling growth of safflower (Carthamus tinctorius L.). Seed Sci. Technol., 38: 73-78.

Ganiger, B S., Basave Gowda., K Lokesh, and G Y Lokesh., Umesh Hiremath and M S Harish., 2019. Standardization of sieve size for seed grading in soybean. Int. J. Curr. Microbiol. App. Sci., Special Issue-9: 7177.

Ghorbani, M H., A Soltani and S Amiri., 2008. The effect of salinity and seed size on response of wheat germination and seedling growth. J. Agric. Sci. Natur. Resour, 14(6).

Gunaga, R P., Hareesh, TS and Vasudeva, R., 2007. Effect of fruit size on early seedling vigour and Biomass in White Dammer (Vateria indica): a vulnerable and economically important tree species of the Western Ghats. J. NTFPs, 14: 197-200.

Hanumantharaya, J., 1991. Performance evaluation of air screen seed cleaner for paddy, redgram and sunflower seeds. M.Sc. (Agri.) thesis submitted to Univ. Agric. Sci., Bangalore, India.

Hedley, C L., 2001. Carbohydrates in grain legume seeds: Improving nutritional quality and agronomic characteristics. Wallingford, Oxon, GBR: CABI Publishing, pp. 1-14.

Hulse, J H., 1991. Nature, composition and utilization of grain legumes. In: Patencheru, A.P. (Ed), Uses of tropical legumes. Proceedings of a consultants meeting, 2730 March 1989. pp. 502-524.

Jerlin, R and K K Vadivelu., 2004. Effect of fertilizer application in nursery for elite seedlings production of pungam (Pongamia pinnata L. Picrre). J. Trop. Agri. Res. Extension.

Jesse E Harmond., Leonard M Klein and N Robert Brandenburg., 1961. Seed cleaning and handling. Agricultural Research Service, United State Department of Agriculture, Agriculture Handbook No, 179. Pp 1-38.

Kumar, A., R P S, Tomar., R Kumar and R S Chaudhary., 2005. Seed size studies in relation to yield attributing parameters in Indian mustard (Brassica juncea (L) Czern and Coss). Seed Res., 33(1): 54-56.
Mathur, P N., N C Sinha and R P Singh., 1982. Effect of seed size on germination and seed vigour in oat (Avena sativa $\mathrm{L}$.). Seed Res., 10: 109-113.

Menaka, C and P Balamurugan., 2008. Seed grading techniques in Amaranthus cv. CO5. Plant Arch., 8:729-731.

Morrison, M J and Xue, A G., 2007. The influence of seed size on soybean yield in short- season region. Canadian Journal of Plant Sciences., 87:89-91.

Ramaiah, H. 1994. Studies on some seed technological aspects of sunflower (Helianthus annuus L.) hybrids and their parents. Ph.D. thesis submitted to Univ. Agric. Sci., Bangalore, India.

Ramesh, D., 1996. Studies on enhancement of seed germination and vigour in carrot (Daucus carota L.) cv. Zino. M.Sc. Thesis, Tamilnadu Agricultural University, Coimbatore.

Roozrokh, M., Shams, K and vghar, M., 2005. Effects of seed size and seedling depth on seed vigor of chiek pea, First National Legume Congress. Mashhad Ferdowsi. University, Mashhad, Iran.

Rukavina, H., I Kolak, H Sarcevic and Z Satovic., 2002. Seed size, yield and harvest characteristics of three Croatain spring malting barleys. Bodenkultur, 53(1).

Suma, N., P Srimathi, and S Sumathi., 2014. Influence of size grading on seed and seedling quality characteristics of Sesamum indicum. Int. J. Curr. Microbiol. App. Sci., 3(6):486-490.

Vishwanath and Ravi Hunje., 2018. Influence of seed size grading on seed quality of soybean variety DSb-21. J. Farm Sci., 31(4): 388-391.

Willenborg, C.J., J C Wildeman, A K Miller, B G Rossnaged and S J Shirtliffe., 2005. Oat Germination Characteristics Differ among Genotypes, Seed Sizes and Osmotic Potentials. Crop Science, 45: 2023-2029.

Williams P C and Singh, U., 1988. Quality screening and evaluation in pulse breeding. In: Summerfield RJ (ed.) World crops, cool season food legumes. Kluwer Academic Publishers, Dordrecht, pp. 445-457. 


\section{How to cite this article:}

Ganiger, B. S., Basave Gowda, Umesh Hiremath, G. Y. Lokesh and Rekha, L. 2020. Seed Size Studies in Relation to Quality Attributing Parameters in Chickpea Variety GBM-2. Int.J.Curr.Microbiol.App.Sci. 9(07): 1694-1702. doi: https://doi.org/10.20546/ijcmas.2020.907.195 